\title{
THE EFFICIENCY ASSESSMENT OF THE STATE SYSTEM OF NUCLEAR SAFETY CONTROL OF NSC-SO
}

\author{
R.L. Godun, A.O. Doroshenko, D.O. Muliar \\ Institute for Safety Problems of Nuclear Power Plants NAS of Ukraine, \\ Chornobyl, Ukraine \\ E-mail: ispnpp@ispnpp.kiev.ua; fax 5-14-34, tel.(04593) 5-10-44
}

According to the results of a comprehensive analysis, it was found that the nuclear safety monitoring system (NSMS) does not fully comply with the requirements put forward to it. By assessing the sufficiency of the detection points of this monitoring system, it was found that there is no monitoring at the cluster of nuclear fissile materials (NFM) in the central hall and at the "northern" cluster in 305/2 rooms. The effectiveness of monitoring the "southern" cluster of NFM in the room. 305/2 is insufficient and does not comply with the standards regulated by the rules of nuclear safety. Also, a number of other requirements to the NSMS (as the emergency alarm systems of the spent nuclear waste storage facility) are not fulfilled. It is proposed to re-arrange the measuring channels (MC) of the system, decommission excess (non-informative) MC and use their equipment to organize new effective monitoring points; to upgrade the software and arrange individual ground of the system to reduce the influence of high-frequency interference.

\section{INTRODUCTION}

Nuclear safety (NS) of the New Safe Confinement (NSC) complex can be ensured only if there is effective monitoring of the neutron activity of clusters of nuclear hazardous fissile materials (NHFM) in the premises of the Shelter object (SO) formed as a result of a severe beyond design basis accident at the fourth power unit Chernobyl nuclear power plant.

The NSMS of the Integrated Automated Monitoring System (IAMS) successfully passed metrological certification and was put into experimental testing in 2014, and from 2016 to regular operation. NSMS IAMS continuously (in automatic mode) registers the neutron flux density (NFD) and the gamma dose rate (GDR) inside the NSC-SO complex and accumulates the measurement results in a centralized database, as a result of which there are continuous regular series of data allowing the analysis of these parameters. According to the results of the analysis of continuous monitoring of NFD, it was found that in some measuring channels (MC) there are periods when there are no measurements, and in some MC there are sharp jumps in the recorded neutron activity (Fig. 1).

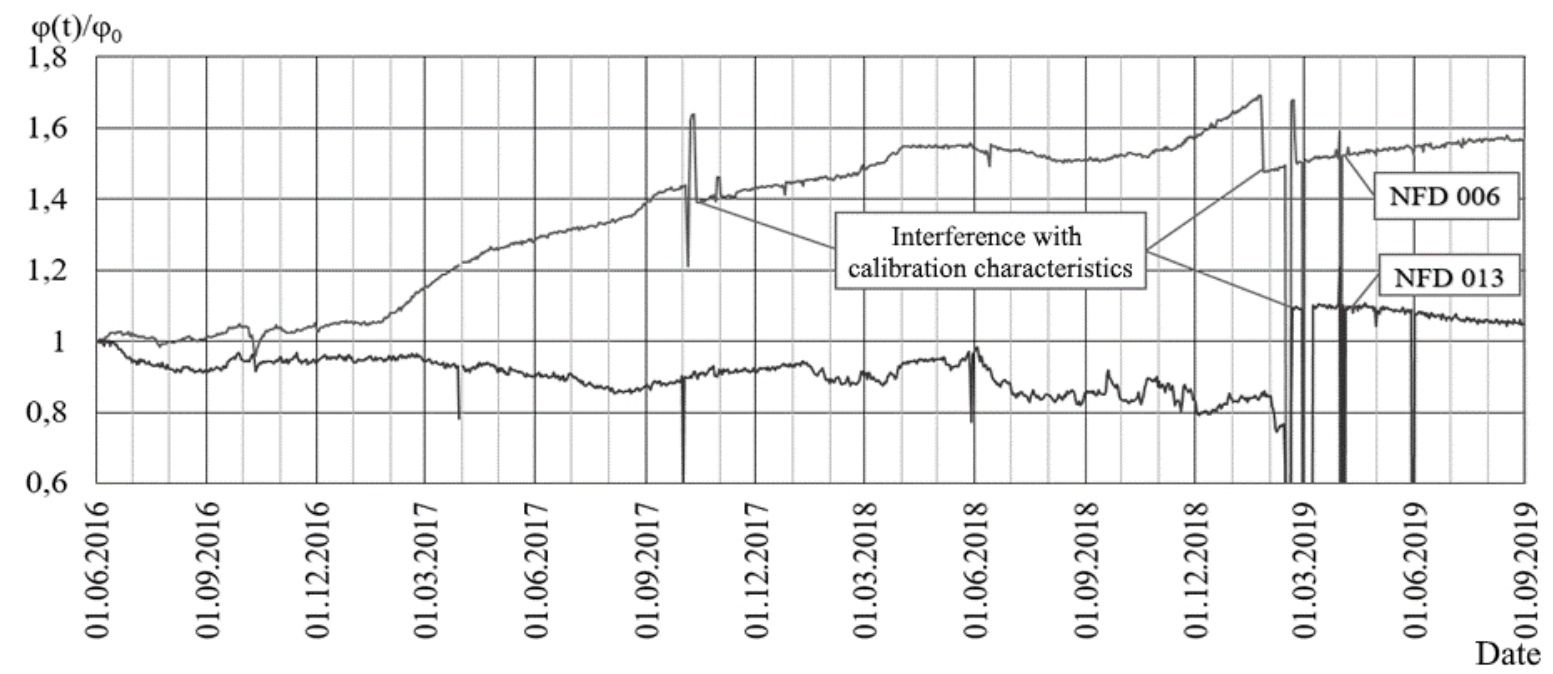

Fig. 1. The dynamics of NFD in MC NSMS, in which unauthorized operator intervention

The absence of NFD measurements is due to the fact that these MC are taken out of operational service, while there is no backup equipment, which does not allow for continuous measurement of parameters, and also in the event of failure of the MC elements, they can be restored to serviceability during the routine $72 \mathrm{~h}$. Regarding drastic changes recorded by the NFD, they are not associated with real physical processes within the controlled facility, but only with the intervention of operational personnel. These jumps are most likely the result of changes in the discriminatory characteristics in the NSMS (changes in the discrimination thresholds) and/or non-observance of the exact coordinates of the installation of the detection units (DU) when they are reinstalled, which with a strong dependence of the fission chamber (FC) on the neutron spectrum (estimated by the cadmium ratio - Rcd) leads to a significant change in the recorded NFD [1].

In any case, both variants of such interventions in the operation of the metrologically certified nuclear safety system of the NSC-SO complex are an 
unauthorized violation of the operating conditions of the NSMS and should be excluded in the future.

The relevance of the study to evaluate the effectiveness of the work of the NSMS is mainly determined by the fact that at the moment the issue of nuclear safety is not given due attention. The last comprehensive analysis of the nuclear safety factor was performed in 2009 [2]. After that, the operator of the ChNPP provides only short informational reports [3-5], in which several (3-4) pages are devoted to the problem of nuclear safety. The following information is provided in these reports: localization of the monitoring points of the regulatory NSMS, the measurement results of some non-informative $\mathrm{MC}$, and indicates that the operational control function of dangerous changes in subcritical is assigned to the gadolinium solution supply system and the modernized dust suppression system. The conclusions of these reports state that "... there are no anomalies or incidents, which are caused by the constant increase in the power of the NFD, and control systems for the free period are not fixed ...". Thus, the fact is ignored that in several MC for more than two years there has been a constant increase in NFD from 20 to $90 \%$ (Fig. 2).

Considering the fact that the nuclear research and storage facilities are poorly researched and controlled (there is no direct access to them) in the central hall and room 305/2, which, according to various estimates, has about 80 tons of spent nuclear fuel (SNF) [6-8] (which is more than enough for the formation of a critical composition), then we can state the following: this situation is unacceptable because now the SO does not meet the generally accepted safety requirements put forward to the complex NSC-SO (nuclear hazardous facility).

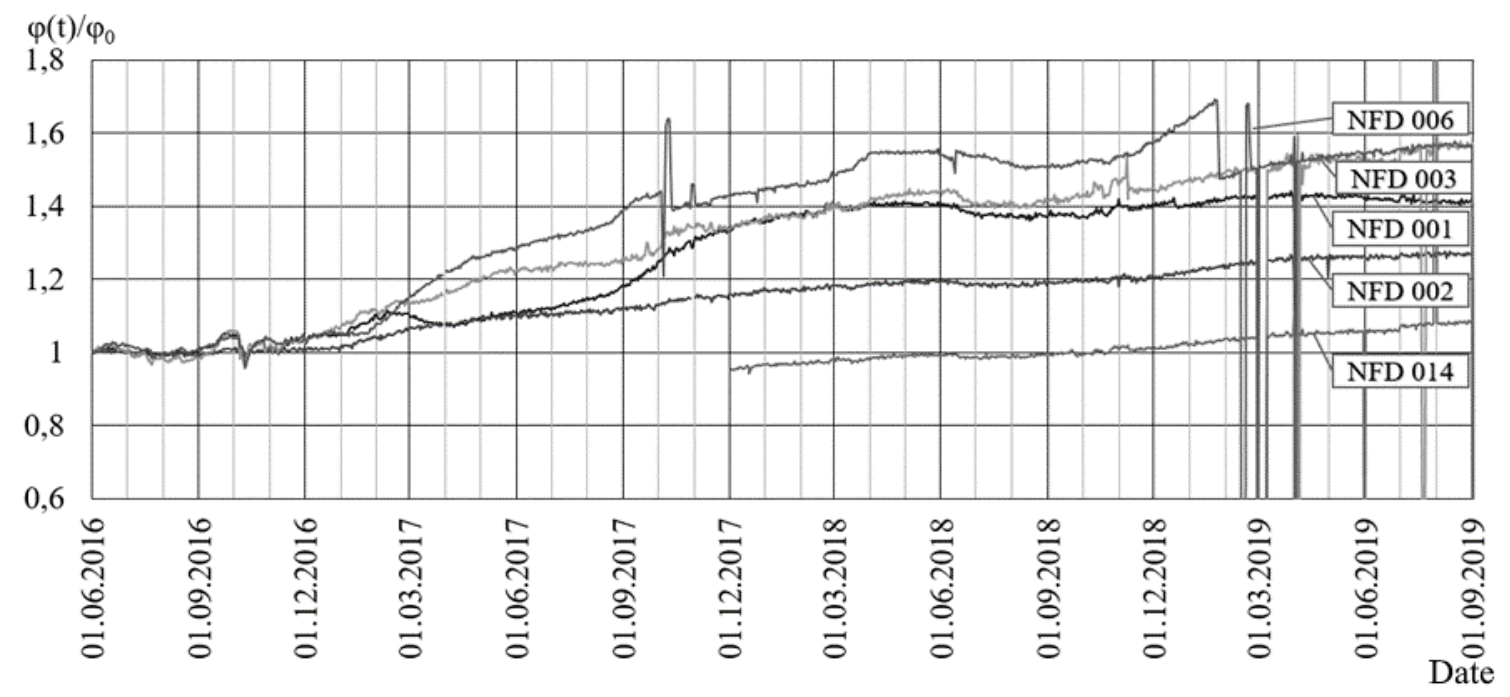

Fig. 2. Measuring channels with stable NFD growth

\section{ANALYSIS OF COMPLIANCE WITH NSMS REGULATORY REQUIREMENTS}

The current state of the SO [9] is qualified as follows: "SO is the 4th Chernobyl NPP unit destroyed by a beyond design basis accident, which lost all the functional properties of the power unit and on which priority measures were taken to reduce the consequences of the accident, and work is continuing to ensure its nuclear and radiation safety "[10]; SO in its current state should be classified as "... the temporary storage of non-organized radioactive waste (RW), is in the process of stabilization and reconstruction" [11].

From the above provisions, it follows that activities at the SO (NSC) are radioactive waste management activities. Accordingly, regulation of its safety should be carried out on the basis of regulatory legal acts and scientific and technical documentation [12, 13] operating in the field of radioactive waste management. Thus, in order to comply with the basic principles and the nature of technical and organizational measures aimed at achieving nuclear and radiation safety, for the NSC-SO complex to apply the "Nuclear Safety Rules" (NSR) [14] and [15, 16]. NSR-90/99 to the NSMS as an alarm system for the radioactive waste storage facility (nuclear hazardous facility) is regulated by the following requirements:

1. "If the nuclear hazard zone includes a collection of separate buildings or adjacent rooms, then the detection units (DU) and alarm devices are installed in those buildings and rooms where the possibility of a self-sustaining chain reaction (SCR) is not excluded" (paragraph 2.2.7).

2. The threshold for the operation of alarm systems in accordance with clause 2.2.2 is determined by the requirement to detect a minimum $\mathrm{SCR}$, which creates a dose of $0.25 \mathrm{~Gy}(25 \mathrm{rad})$ for no more than $60 \mathrm{~s}$ at a distance of $1 \mathrm{~m}$ from the place of occurrence in the absence of absorbing screens (i.e., during the accepted maximum duration of the SCR peak). Moreover, "response thresholds in NFD units should be determined to take into account the energy dependence of their spectrum and the sensitivity of the DU" (paragraph 2.2.4).

3. The angular dependence of the efficiency of the DU of the detected radiation should be no more than $25 \%$ and is given in the documentation for these DU (paragraph 2.2.10).

4. Alarm systems should be designed, manufactured and placed (mounted) in such a way as to ensure its 
reliable and long-term continuous operation in a production environment (paragraph 2.5.1).

Based on the results of the analysis of NSMS, the following conclusions are made:

1. The requirements of paragraph 2.2.7 of the NSR are not fulfilled, since the availability of effective monitoring points in all rooms where "the likelihood of an SCR is not excluded" is not implemented. More detailed information is presented in the section "Assessment of the sufficiency and effectiveness of detection points for the SO nuclear safety system".

2. The requirements of paragraph 2.2.2 are also not fulfilled, which will be justified below. Moreover, according to the NSR "if the system is based on recording the dose rate of the neutron radiation, the response threshold should not exceed $1 / r^{2} \mathrm{mGy} / \mathrm{s}(r$ is the distance in meters from the place of the possible occurrence of the SCR to the DU), and the dose of neutron radiation should be up to the moment of operation of the unit detection should be no more than $3 / \mathrm{r}^{2} \mathrm{mGy}$ ". The requirements of paragraph 2.2.4 are also not fulfilled because the NFD at the control points should be determined to take into account the individual energy dependence of the spectrum and the sensitivity of each DU. For the DU NSMS (FC216 / 2000 / U235), spectral dependences were not obtained under the real conditions of the NSC-SO. The existing spectral dependences (constructed for the FC KNT-31) were taken on the basis of the analogy method. FC NSMS and KNT-31 have a number of differences in the characteristics of the radiator (active layer consisting of uranium isotopes), therefore, this should be verified experimentally.

3. The requirements of 2.2 .10 are not fulfilled, because according to the technical documentation [17] on NSMS, the DU efficiency has a strong angular dependence (when the neutron beam changes by $90^{\circ}$, the response changes by a factor of 7-8).

4. The requirements of paragraph 2.5.1 are not fulfilled (see Fig. 1), in addition, the lack of backup equipment (at the moment there is only one incomplete set for $19 \mathrm{MC}$ in the reserve) in the event of a failure of one of the equipment, it will not allow to restore the System within a permissible $72 \mathrm{~h}$.

\section{ASSESSMENT OF THE SUFFICIENCY AND EFFECTIVENESS OF DETECTION POINTS FOR THE SO NUCLEAR SAFETY SYSTEM}

NSMS is a complex of 19 MC that register of NFD and GDR at the control points. At the same time, a part of the MC equipment (detectors, preliminary and main amplifiers, etc.) was designed for use in standard monitoring channels NFD of nuclear power reactors (the equipment is designed for large neutron fluxes), which does not correspond to the current operating conditions.

The control of GDR (as a parameter concomitant with neutron activity from accumulations of NHFM) is not informative. This is due to the fact that the GDR level by gamma radiation from fission events and decay chains of fission fragments is orders of magnitude lower than the level detected by the gamma background (the monitoring points of the routine NSMS IAMS are in fields with GDR values of several hundred/thousand $\mathrm{x}$ rays). According to the calculations, when SCR occurs at the regulatory monitoring points, reliable registration of GDR changes (detectable excess over the background level) is possible only with a number of divisions of the order of $10^{15} \ldots 10^{16}$, which (taking into account the increasing kinetics/speed in the near-critical zone) does not allow using this parameter to prevent the occurrence of SCR [18].

In the regular system of IAMS, temperature control at the places of accumulation of fuel-containing materials (FCM) was not provided. Although this control parameter (temperature) is not the main criterion in assessing the stability state of FCM clusters, the data on temperature fields in the SO rooms provide a general idea of temporary changes in energy release from the FCM cluster and are taken into account when assessing the boundaries of FCM clusters.

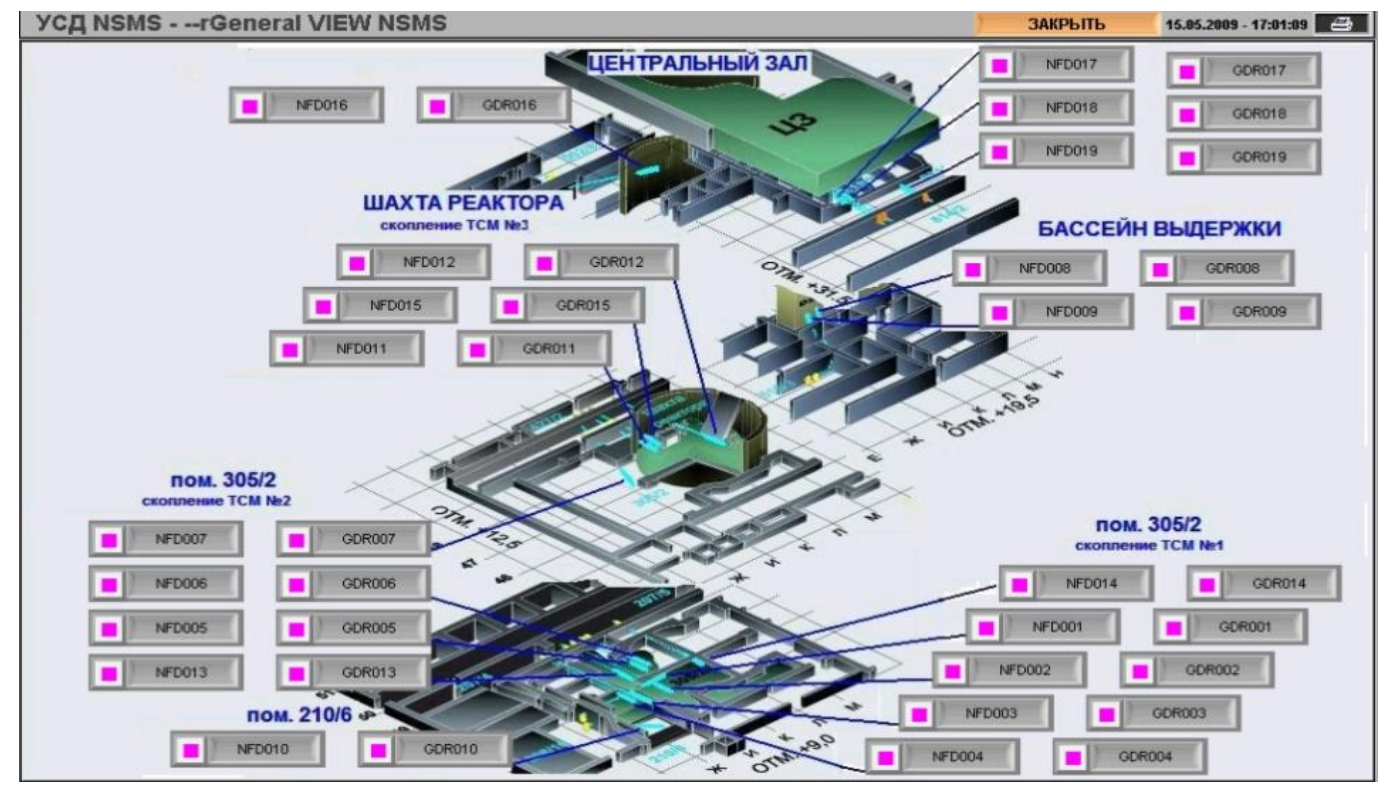

Fig. 3. Localization of monitoring points for MC NFD NSMS 
In the report on the results of the analysis of the current SO safety [19-21], based on experimental and calculated estimates, the premises were classified according to the degree of nuclear hazard of FCM accumulations located in them. The following premises were identified as potentially nuclear-hazardous the central hall $(\mathrm{CH})$, the southern exposure pool, the reactor shaft, and the underreactor room 305/2. In these rooms, "the existence of compositions in which the occurrence of SCR is fundamentally possible" was allowed.

At the same time, current monitoring of the FCM NFD inside the NSC-SO complex is carried out (Fig. 3) in the following rooms: reactor space (at elevations from +15.00 to +22.00 ); $305 / 2$ (at elevations +12.00 ; +9.00 ); $304 / 3$ (at +10.00 ); steam distribution corridor (at $+6.50)$; the southern exposure pool (at +19.00 and $+22.00)$; in tunnels under the central lock (at +33.00).

The standard detection points for NSMS, which were selected according to the recommendations of 2001 [23], are currently largely uninformative for the purpose of providing nuclear safety since over the past
15 years the information on the parameters and localization of the main clusters of NHFM has changed significantly. Now the most potentially dangerous is the central hall and room 305/2 [22]. The estimated area of accumulation of NHFM in the $\mathrm{CH}$ requiring continuous monitoring is limited by the following coordinates: altitude level from $35.00 \mathrm{~m}$ to $37.00 \mathrm{~m}$, between the axes $40.00-46.00$, rows I $-\mathrm{N}$, the coordinate system 4th unit of the ChNPP. In this zone, the nearest neutron detectors (DU NFD No. 017, 018, 019) of the NSMS are installed in the tunnels under the lower central overlap (altitude $33 \mathrm{~m}$ ) and are uninformative due to weakening (at least 103 times less) of the FC response to neutron incident. Thus, the DU NSMS will not respond in a timely manner to changes in neutron activity with the possible occurrence of SCR, and the cluster of FCM in the $\mathrm{CH}$ is not currently monitored. Also, NSMS has practically no control over the "northern" NHFM cluster in room 305/2, which is clearly visible on temperature field maps (Fig. 4). There are no monitoring points in the zone of localization of this potentially nuclear hazardous cluster.

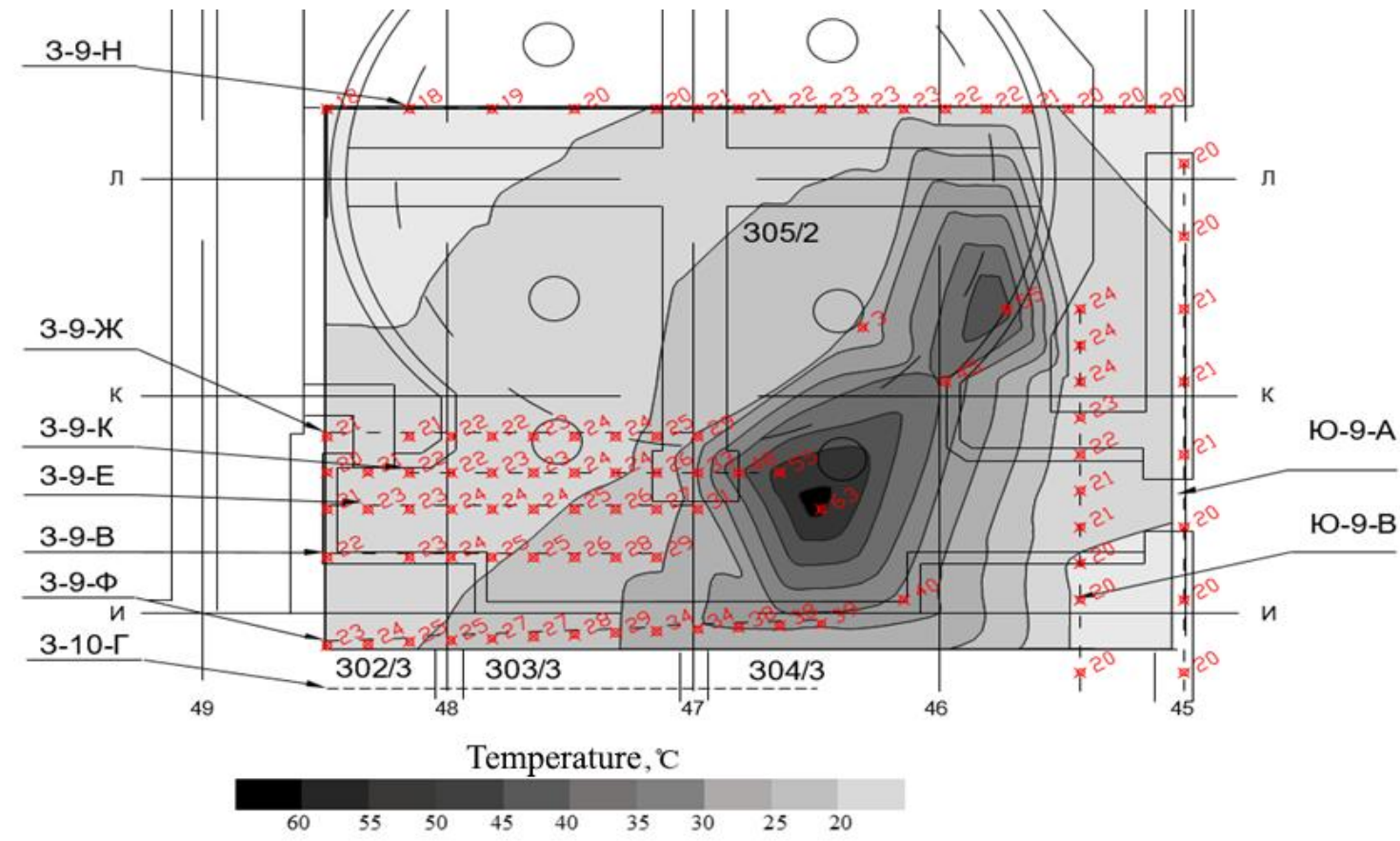

Fig. 4. Temperature fields in the area of localization of NHFM (top view of the underreactor plate, mark +9.00 )

In the zone of localization of the "southern" cluster of NHFM in room 305/2, the closest to the source are the DU MC NFD No. 01, 03 and 04 (Fig. 5), while:

1. Detector MC NFD No. 1 is installed through borehole $\mathrm{Yu}-12-78$ (in the space above the zone of location of the FCM cluster) at +12.00 and the partition environment between the DU and the NHFM cluster are black LFCM layer $(0.6 \mathrm{~m})$, layer $(0.8 \mathrm{~m})$ of heavy concrete and $1.5 \mathrm{~m}$ of air.
2. Detector MC NFD No. 3 is installed in the concrete of the underreactor plate (in borehole Z-9-F) at the level of $+9.30 \mathrm{~m}$ and the partition environment between the DU and the NHFM cluster are a layer $(1.5 \mathrm{~m})$ of heavy concrete and a layer $(1,0 \mathrm{~m})$ LFCM.

3. Detector MC NFD No. 4 is installed in room $304 / 3$ (through borehole Z-10-G) on the surface of the LFCM (elevation + 9.70) and the partition environment between the DU and the NHFM cluster is: a layer $(2.5 \mathrm{~m})$ of LFCM or meter heavy concrete layer. 


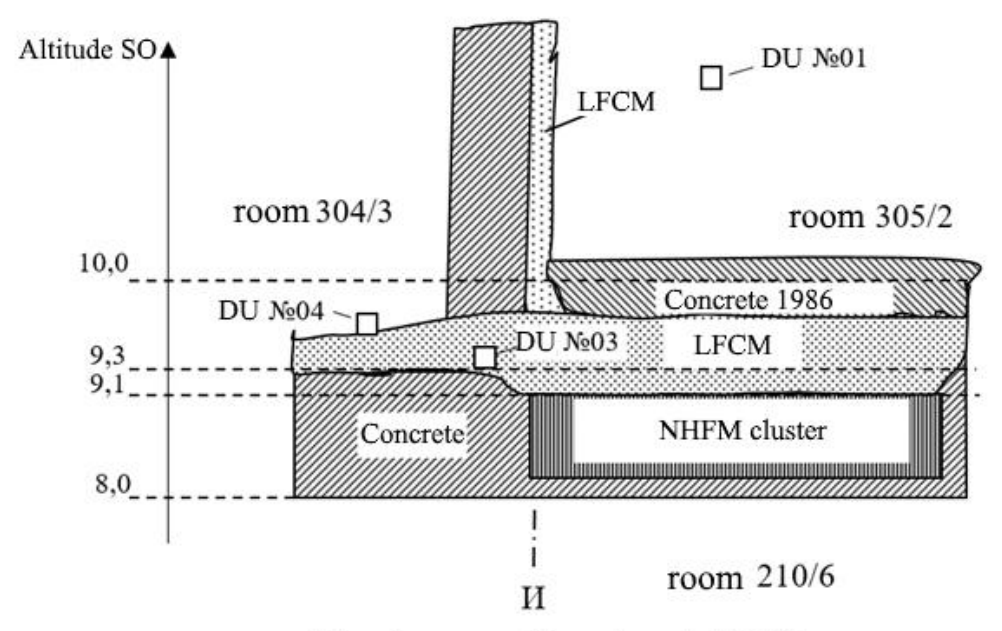

$\square-$ placement of detection units NSMS
Fig. 5. The estimated cross-section in the zone of localization of the "southern" cluster of NHFM in room 305/2,
indicating the localization of the nearest NSMS DU

The informational sufficiency of the obtained data on the subcritical state of NHFM clusters primarily depends on the location of the detectors relative to the controlled sources, because the radiation of neutrons

and gamma rays of the sensor (due to their absorption in FCM, structures, etc.) is effectively recorded only in a limited distance (Table 1).

The maximum value of the response threshold of the DU and the maximum distance from the DU to the place of the possible occurrence of SCR at various absorbing thicknesses materials located between the DU and the location of the SCR [16]

\begin{tabular}{|c|c|c|c|c|c|c|}
\hline \multirow{3}{*}{$\begin{array}{l}\text { The thickness of the } \\
\text { absorbing material, m }\end{array}$} & \multicolumn{6}{|c|}{ Registered radiation - neutrons, absorbing material - concrete } \\
\hline & \multicolumn{3}{|c|}{$\begin{array}{l}\text { The maximum distance from the DU to the } \\
\text { place of the possible occurrence of SCR, m }\end{array}$} & \multicolumn{3}{|c|}{$\begin{array}{l}\text { The maximum value of the DU response } \\
\text { threshold, } \mu \mathrm{Rad} / \mathrm{s}\end{array}$} \\
\hline & $\rho=2.2$ & $\rho=3.2$ & $\rho=4.2$ & $\rho=4.2$ & $\rho=3.2$ & $\rho=4.2$ \\
\hline 0 & 30 & 100 & 100 & 100 & 30 & 30 \\
\hline 0.40 & 10 & 11 & 4 & 4 & 5 & 6 \\
\hline 0.50 & 7 & 5 & 1 & 1 & 3 & 3 \\
\hline 0.60 & 4 & 2 & - & - & 1 & 1 \\
\hline 0.70 & 3 & 1 & - & - & - & - \\
\hline
\end{tabular}

Note: $\rho$ - this is the density of the material in units of $\mathrm{t} / \mathrm{m}^{3}$; given distances are conservatively rounded to integer values; linear interpolation of data is allowed to determine intermediate values.

Thus, it is necessary to carry out calculations in order to assess the conformity of the detection points of the NSMS with the requirements of paragraph 2.2.22.2.5 [15, 16]. In this case, the location of the DU should be selected in such a way as to avoid affecting the choice of thresholds for the operation of significant absorption of the recorded radiation by structural materials, equipment, walls of premises. The influence of absorption is allowed to be neglected when its multiplicity is not more than 1.5 . If it is impossible to eliminate significant absorption of radiation from the site of the possible occurrence of the SCR to the detection units, the latter must be brought closer to the controlled equipment or the threshold of the system should be lowered so that the requirements of the above points are satisfied.

Based on the results of assessments of the distance from the "southern" cluster of NHFM to the DU of the MC NSMS, as well as the partitioned environment between them, it was concluded that these detection points do not meet the regulated requirements of the NSR regarding the maximum distance from the DU to the place of the possible occurrence of SCR.

As intermediate results, it can be argued that the existing information capacity of the NSMS is insufficient due to the lack of:

- control points in the zone of localization of NHFM clusters, "in which the occurrence of SCR is possible" (CH, "northern" cluster in room 305/2), as well as low efficiency/informational content of control points in the zone of localization of the potentially most dangerous "southern" cluster NHFM of room 305/2, in which about 20 tons of spent fuel in a compact composition [22];

- duplication of detection points in the localization zone of NHFM (production facilities, temporary storage sites for NHFM, where SCR may occur, should be monitored by at least two independent DU. The DU is accepted independent if the failure of any of them does 
not affect the operability of others. Alarm should trigger from any of the two DU [16]).

In addition to the analysis of the adequacy of the control points of the NSMS, an analysis was made of the location of each DU of the MC NSMS, according to the results of which the following was established:

1. DU MC NFD No. 01 (BH U-12-78), 03 (BH Z-9F), 06 (BH Z-9-68), 07 (BH Z-16-61), 04 (BH Z-10 -G), 10 (BH Yu-9-D), 11 (BH Z-15-D) and 15 (BH Z-15-Zh) are located in the localization zone of the main clusters of NHFM, therefore, they can be used to control their subcritical.

2. Due to the spatial distance from potentially dangerous accumulations of NHFM, detectors MC NFD No. 05 (BH Z-9-Zh), 08 (BH V-21-96), 09 (BH V-19103), 12 (BH Z-15 -B), 14 (BH Z-9-Ch), 16 (BH 3-22B), MC No. 17-19 are practically uninformative. This is especially true for BH No. 17-19, in which there is no controlled parameter. The DU of these MC NSMS is located on the periphery of FCM clusters in which the

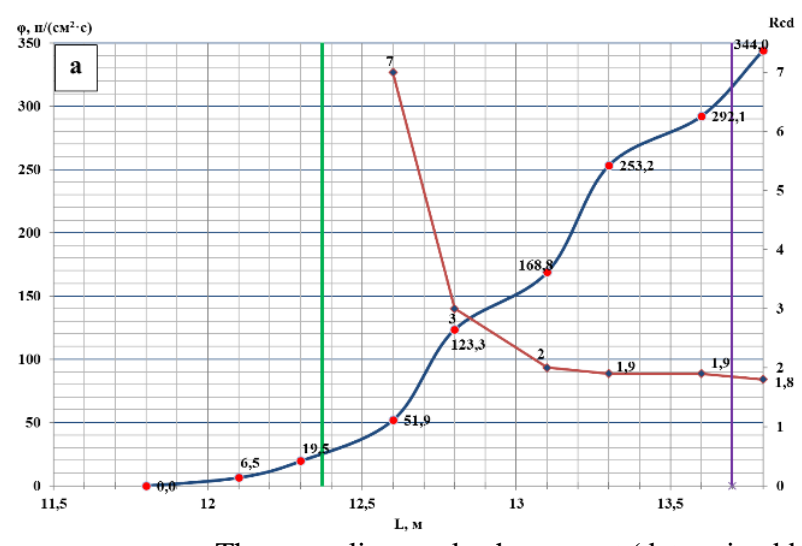

The green line marks the current (determined by the casing depth) coordinate of the DU center, purple - optimal

Fig. 6. The expected values of NFD and Rcd along the length of the BH Z-9-K, in which the DU NFD No. 02 (a) is installed and for the BH Z-9-V DU NFD No. 13 (b)

The recorded NSMS NFD is obtained by multiplying the MC sensitivity coefficient by the count rate in this channel. The sensitivity coefficients of each MC NFD are individual and are estimated by the measured Rcd value at the monitoring point, the values of which can vary greatly along with the depth of the MC (see Fig. 6). The last measurements of cadmium ratios (see Fig. 6) in the MC in which the detectors were installed were performed in 1989-1990. In this regard, it is desirable to re-conduct the work on the experimental removal of Rcd depending on the depth of installation (from the wellhead) of the FC (Fig. 7). occurrence of SCR is impossible [18-22]. Thus, the current circuit of the detection points of the NSMS is unnecessary, not effective, and should be adjusted.

It should also be noted that the neutron detectors and GDR sensors of the MC NSMS are located in research borehole $(\mathrm{BH})$ in different rooms throughout the entire volume of the NSC-SO complex. To isolate the DU from the negative effects of water, MC is cased (sealed) with pipes. It was shown in [24] that during the preparation of MC for NSMS, their available depth decreased significantly due to their sealing with casing pipes; therefore, DU NSMS is located further from the localization zones of NHFM clusters. In this regard, several of the most informative points were lost, because due to sealing there were restrictions on the depth of the possible installation of the DU. For example, in MC NFD No. 02 (BH Z-9-K), 13 (BH Z$15-\mathrm{V}), 15$ (BH Z-15-Zh) the monitoring efficiency was lost due to the inability to install sensors at informative points after execution BH casing (Fig. 6).

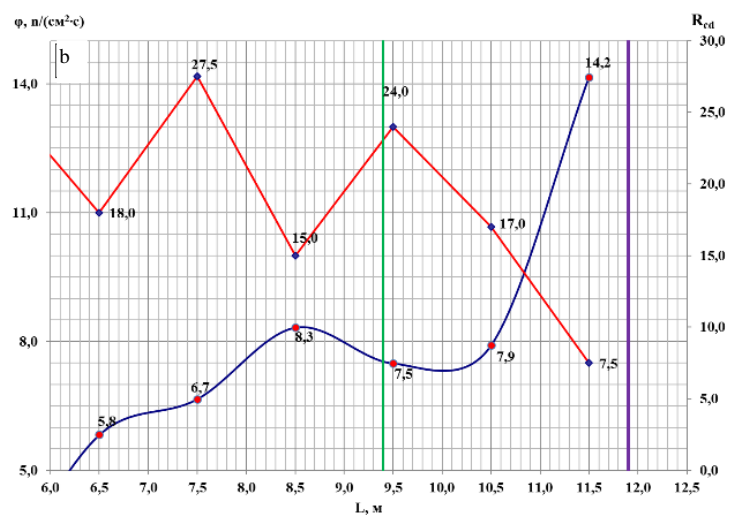

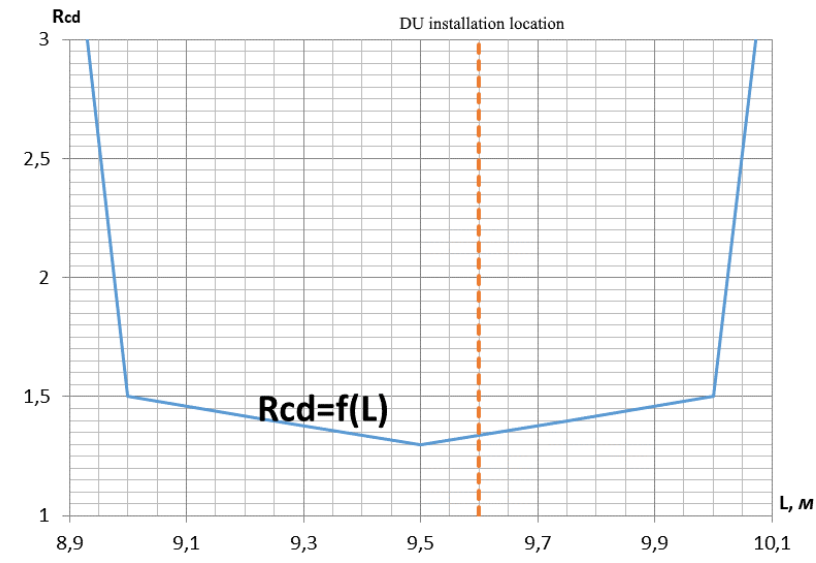

Fig. 7. The dependence of the cadmium ratio from the coordinates of the FC installation in MC No. 05 


\section{RECOMMENDATIONS FOR BETWEEN NSMS IAMS IN ACCORDANCE WITH REGULATED REQUIREMENTS, AND ALSO INCREASING ITS EFFICIENCY}

Obviously, in the localization zone of each NHFM cluster, the total number and location of the monitoring centers for NSMS is determined by the real possibilities of their approach to a controlled source and financial possibility. The greatest monitoring efficiency would be obtained when the detectors were installed directly in the volumes of NHFM clusters, however, this is a complex and expensive technological task, which is now difficult to solve in the current realities. Therefore, a set of optimal and economically acceptable measures has been proposed that can significantly increase the effectiveness of the NSMS and bring it in line with regulatory requirements.

1. Improving the efficiency of NSMS is possible by optimizing/correcting MC and changing the localization of some DU. It is proposed to decommission non- informative (for the purpose of providing NS) MC NFD No. 12-19. It is proposed to use the "freed up" equipment of these MC for organizing new effective detection points and/or as backup equipment for restoring the operability of informative MC.

2. An increase in the information content of NSMS can be achieved due to the maximum approximation of the location of the DU of existing MC sources to the sources (table 2) and the implementation of new informative points for detecting NFD (primarily in rooms 305/2 and $\mathrm{CH}$ ). The effectiveness of monitoring the neutron activity of the "southern" cluster of NHFM in room 305/2 can be improved by removing the casing from the BH Z-9-K, Z-9-Zh and further reinstalling the DU located in them at more informative points (located closer to the source ) Monitoring of the neutron activity of the "northern" cluster of NHFM in room 305/2 can be realized after the detectors are installed in room 307/2 through the BH 3-9-V and V-13-106.

Parameters of the current MC casing used to install the DU NSMS

\begin{tabular}{|l|c|c|c|c|}
\hline \multirow{2}{*}{$\begin{array}{c}\text { Number } \\
\text { MC NSMS }\end{array}$} & \multicolumn{2}{|c|}{\begin{tabular}{c} 
Brief description of the borehole \\
\cline { 2 - 3 }
\end{tabular}} & $\begin{array}{c}\text { Depth of } \\
\text { detector } \\
\text { installation, } \\
\mathrm{m}\end{array}$ & $\begin{array}{c}\text { Recommendations } \\
\text { MC NFD N 1 }\end{array}$ \\
\hline MC NFD N 2 & 13.0 & 11.3 & 11.1 & - \\
\hline MC NFD N 3 & 12.5 & 12.6 & 12.4 & - \\
\hline MC NFD N 4 & $>15$ & 13.9 & 13.7 & - \\
\hline MC NFD N 5 & 13.7 & 14.4 & 14.2 & - \\
\hline MC NFD N 6 & 14.1 & 9.8 & 9.6 & Move 3 m (all the way) \\
\hline MC NFD N 7 & 11.2 & 12.7 & 9.5 & - \\
\hline MC NFD N 8 & 10.76 & 11.2 & 11.0 & - \\
\hline MC NFD N 9 & 11.1 & 10.5 & 10.2 & - \\
\hline MC NFD N 10 & 14.5 & 12.0 & 11.8 & Move 0,9 m (all the way) \\
\hline MC NFD N11 & 12.5 & 12.2 & 11.1 & - \\
\hline
\end{tabular}

3. It is proposed to test the informativeness/effectiveness of the new detection points for NFD with the help of the currently working expert research system of the Institute for Safety Problems of NPPs.

4. In order to reliably ensure monitoring of overhead protection and compliance with the requirements of the NSR, it is necessary to ensure duplication/redundancy of monitoring points for overhead protection. Also, in the localization zone of the potentially most dangerous clusters of nuclear weapons (room 305/2 and $\mathrm{CH}$ ), it is desirable to implement such a number of information points that the requirement of mutual overlap of the monitored FCM arrays is fulfilled, which will make it possible to repair or maintain one of the detectors. Therefore, in the localization zone of each cluster of NHFM, there must be at least three DU. At the same time, the requirement of mutual overlap of the controlled volumes of FCM means that the expected rate of attenuation of the response to the anomaly at the nearest detectors should not exceed one order. The degree of mutual overlap of the observation zones of the detectors is proposed to be estimated experimentally (using the short-term introduction of an external neutron source at points with determined coordinates). This approach is caused by the fact that the attenuation of the response of the detector to the source is purely individual for each information point of the controlled object, which is associated with different "geometry of the source-receiver mutual arrangement" (different distance and angular orientation), as well as with various absorbing properties of a particular interface between the source and DU.

5. For reliability of nuclear safety (NFD monitoring), it is also necessary to purchase several spare MC kits so that in the event of a single equipment failure it would be possible to restore the MC operability during the regulated $72 \mathrm{~h}$.

6. A layout of detection points and access routes to them in the central hall is proposed (Table 3), the implementation of which will provide a function for effective monitoring of the state of subcritical in the areas where NHFM clusters are located. The optimal routes for the delivery of detectors to detection point No. 2-4 are penetrations in the pipe run of the roof. Through these penetrations, detectors can be hung out in the given coordinates (at elevations from $+36.00 \mathrm{~m}$ to $+37.00 \mathrm{~m}$ ). Detectors can be delivered to the lower floor 
via well Yu-22-129 from room 515/3. Detectors can be connected to the monitoring system through cable lines that go to rooms 6004 and 208/10. The location of the preamplifiers must be determined in the working order based on restrictions on the length of the permissible distance between the detector and the preamplifier.

Table 3 Location and access routes to detection points in the areas where potentially dangerous nuclear fuel assemblies FCM are located in $\mathrm{CH}$

\begin{tabular}{|c|c|c|c|c|c|c|c|c|c|}
\hline \multirow{2}{*}{ 㞐 } & \multirow{2}{*}{ 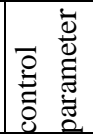 } & \multicolumn{2}{|c|}{ Control Point Coordinates } & \multirow{2}{*}{$\begin{array}{l}\text { Delivery } \\
\text { route }\end{array}$} & \multicolumn{3}{|c|}{ Route Characteristics } & \multicolumn{2}{|c|}{ Cable exit address } \\
\hline & & Altitude & Coordinates & & Beginning & Coordinates & $\begin{array}{c}\text { Diameter, } \\
\mathrm{mm}\end{array}$ & $\begin{array}{l}\text { No. } \\
\text { room. }\end{array}$ & $\begin{array}{l}\text { No. } \\
\text { box }\end{array}$ \\
\hline 1 & $\begin{array}{l}\text { NFD, } \\
\text { GDR }\end{array}$ & +35.00 & $\mathrm{~K} ; 42$ & $\begin{array}{c}\text { Slant } \\
\text { borehole }\end{array}$ & $515 / 3$ & И43; 22 & 127 & $208 / 10$ & Д11 \\
\hline 2 & $\begin{array}{l}\text { NFD, } \\
\text { GDR }\end{array}$ & +37.00 & К-Л; 45-46 & Sunroof & Pipe roll & $\begin{array}{l}\text { К-Л; 45-46; } \\
\text { отм. }+72,00\end{array}$ & 200 & 6004 & Д5 \\
\hline 3 & $\begin{array}{l}\text { NFD, } \\
\text { GDR }\end{array}$ & +37.00 & Л-М; 45-46 & Sunroof & Pipe roll & $\begin{array}{l}\text { Л-М; 44-45; } \\
\text { отм. }+72,00\end{array}$ & 200 & 6004 & Д5 \\
\hline 4 & $\begin{array}{l}\text { NFD, } \\
\text { GDR }\end{array}$ & +37.00 & Л-М; 40-41 & Sunroof & Pipe roll & $\begin{array}{l}\text { Л-М; 40-41; } \\
\text { отм. }+72,00\end{array}$ & 200 & 6004 & Д5 \\
\hline
\end{tabular}

\section{CONCLUSION}

Based on the results of a comprehensive analysis, it was established that NSMS (as a system of routine monitoring of the nuclear safety of a $\mathrm{SO}$ - a temporary storage facility of SNF) does not fully meet the requirements put forward by it, in particular: monitoring of all NHFM clusters in the scope of which the occurrence of SCR is possible ( $\mathrm{CH}$ and room 305/2); the requirement for the maximum distance from the DU to the point of the possible occurrence of the SCR is not complied with; individual response thresholds for specific detection points were not evaluated (not calculated); the requirement that "NFD at the control points should be determined to take into account the individual energy dependence of the spectrum and the sensitivity of each DU" has not been practically fulfilled since the decision to use the characteristics of other fission cameras has not been verified/confirmed (KNT31). In addition, the efficiency of the FC MC NFD NSMS $\left(F C 216 / 2000 / \mathrm{U}^{235}\right)$ has a strong angular dependence, significantly exceeding the permissible; there is no backup/spare equipment, which in the future, in the event of a single failure of the MC, will inevitably lead to a violation of the requirement for continuity of measurements. In addition, unacceptable violations of the rules/norms of operation of the attorney/certified regulatory system for monitoring a nuclear hazardous facility are recorded, namely: unauthorized interventions in the measuring and converting paths of the MC (changes in discrimination thresholds attenuation coefficients); non-informative data are transferred to the controlling state bodies, while dangerous changes in the dynamics of the NFD, which have been recorded for more than two years, are ignored.

There are other problems: the measuring equipment of the NSMS is not provided with individual ground, but is grounded to the general circuit of the SO, which significantly reduces the noise immunity of the $\mathrm{MC}$ system (there are interference in the MC); During the MC casing, informative points were lost, and the existing control points are not optimal. A set of optimal and economically acceptable priority measures has been proposed that can significantly increase the effectiveness of the NSMS and bring it in line with regulatory requirements.

Firstly, according to the results of a comprehensive analysis, it was established that there is "unnecessary" MC whose DU is located far from the accumulations of NHFM and do not participate in the function of providing nuclear safety SO. Therefore, it is necessary to carry out a set of works to evaluate the effectiveness of the NSMS, decommissioning of these "unnecessary"/non-informative MC, and rearrange the NSMS to organize new effective monitoring points with the possibility of using this vacant equipment as a backup. The information content of the new monitoring points can be checked using the expert research system of the Institute for Safety Problems of NPPs. To increase the efficiency of NFD measurements, it is proposed to change the installation coordinates (along with the depth of the MC) of neutron radiation detectors (see Table 2). In addition, it is necessary to carry out evaluative calculations of the adequacy of the control points of the NSMS taking into account the requirements of paragraph 2.2.2-2.2.5 [16], as well as evaluate/calculate the system's compliance with the requirements of duplication and the condition for overlapping nuclear hazardous areas.

It is also necessary to upgrade the software of the NSMS, for which the following is proposed: consider introducing new filters to improve noise immunity (for reliable rejection of knowingly false measurement results caused by high-frequency interference); To identify dangerous changes in the subcritical at the early stages of development, it is necessary to develop and implement an effective (taking into account the twolayer structure of FCM clusters) procedure for identifying dangerous changes in the level of subcritical in the most potentially dangerous clusters of nuclear weapons located in room 305/2.

\section{REFERENCES}

1. The research of the metrological characteristics of the measuring channels of the NSMS IASM in the conditions of the Shelter object of the Chernobyl NPP SSE: Report on the research work / ISP NPP of NAS of Ukraine; hands. V.A. Krasnov. Chernobyl, 2013, 44 p. 
2. Ensuring Nuclear Safety of the Shelter object: Report on the Chernobyl NPP, arch. No. 216-OU, Slavutich, 2009.

3. The Shelter Object Safety Report for 2018. OWSO (NSC) SSE ChNPP. Slavutich - 2019, 53 p.

4. The Shelter Object Safety Report for 2017. OWSO (NSC) SSE ChNPP. Slavutich - 2018, 56 p.

5. The Shelter Object Safety Report for 2016. OWSO (NSC) SSE ChNPP. Slavutich - 2017, 58 p.

6. V.O. Krasnov, A.V. Nosovsky, V.M. Rudko, V.M. Shcherbin. Shelter Object: 30 Years After Accident: Monograph. ISP NPP of NAS of Ukraine Chornobyl, 2016, p. 512.

7. Ye.D. Vysotsky, V.A. Krasnov, A.S. Lagunenko, E.M. Pazukhin. Fuel in room 305/2 of the 4th block of the Chernobyl nuclear power plant. Critical areas. Clarification of the scenario of the formation of lavashaped fuel-containing materials // Problems of nuclear power plants' safety and of Chornobyl. Chornobyl 2007, N 8, p. 77-85

8. A.V. Mikhailov. The results of the calculation of the characteristics of the material environment of nuclear hazardous clusters of the NSC-OU ChNPP for the version of their corium origin // Problems of nuclear power plants' safety and of Chornobyl. 2018, N 31, p. 59-67.

9. Technological regulations of the facility "Shelter of the reactor of Unit 4 of the Chernobyl NPP" 1R-OU, inv. No 74 on $03 / 30 / 2011$.

10. Statement on the policy for regulating nuclear and radiation safety of the Shelter object at the Chernobyl nuclear power plant. Approved by the order of the Minister of 04.04.1998, No. 49.

11. Radiation safety standards of Ukraine. Addition: Radiation protection from sources of potential exposure (NRBU-97/D-2000). Kiev: Ministry of Health of Ukraine, 2000, p. 84.

12. The list of regulatory documents in force at the Chernobyl 3PN-S, 1999, 97 p.

13. Technical assessment of the application for the Shelter object of the list of regulatory legal acts and regulatory technical documents on nuclear and radiation safety: Abstract No. 023611-KNK, SCNAR, 2001, 13 p.

14. The basic rules of nuclear safety in the processing, storage and transportation of nuclear hazardous fissile materials. NSR-06-00-88. M.: State Committee on the Use of Atomic Energy of the USSR. State Nuclear Safety Inspectorate, 1988.
15. Rules for the design and operation of alarm systems about the occurrence of a self-sustaining chain reaction and the organization of measures to limit its consequences (NSR-06-10-91). Approved by the GPAN of the USSR, 1991.

16. Industry rules for the design and operation of alarm systems about the occurrence of a self-sustaining chain reaction and the organization of measures to limit its consequences (NSR-06-10-99), MRFPAE, 1999.

17. NSMS. Description of the system. Identification Number IAMS-NSMS-GS-3101-R. Ansaldo Nucleare, 2005, p. 41.

18. A.A. Borovoy. The Shelter's Carrent Safety Analysis and Situation Development Forecasts (Updated version). Tacis, 1998, p. 104.

19. Analysis of the current security of the Shelter object and forecast estimates of the situation: Report on research (concluding.) / ISTC Shelter of the National Academy of Sciences of Ukraine; responsible executor. A.A. Borovoy. Arch. No. 3836. Chernobyl, 2001, 337 p.

20. Model and experimental research of the effectiveness of neutron monitoring of fuel-containing materials in critical mass risk zones: Report on research / ISP NPP of NAS of Ukraine; responsible executor. A.A. Klyuchnikov. Inv. No. 3886. Chernobyl, 2007.

21. Analysis of the current security of the Shelter object and predictive assessments of the development of the situation: Report on research (concluding) / ISTC Shelter of the National Academy of Sciences of Ukraine; responsible executor. A.A. Borovoy. Arch. No. 3601. Chernobyl, 1996, 272 p.

22. V.O. Krasnov, R.L. Godun. State of fuelcontaining materials inside the Ark NSC and problems related to their nuclear and radiation safety // Problems of Nuclear Power Plants and Chornobyl Safety. 2019, N 32, p. 22-29.

23. Identification of new informative locations for detecting units. borehole verification: Report on R\&D / ISTC "Shelter" of NAS of Ukraine; responsible executor. V.N. Shcherbin. Inv. N 3808. Chernobyl, 2001, $131 \mathrm{p}$.

24. A.I. Dovydkov, V.A. Krasnov, S.A. Dovdykov. About the possibility of using research wells to control fuel-containing materials in the central hall of the Shelter object // Problems of nuclear power plants' safety and of Chornobyl. 2006, N 6, p. 140-144.

Article received 18.02.2020

\section{ОЦЕНКА ЭФФЕКТИВНОСТИ РЕГЛАМЕНТНОЙ СИСТЕМЫ КОНТРОЛЯ ЯДЕРНОЙ БЕЗОПАСНОСТИ КОМПЛЕКСА НБК-ОУ}

\section{Р.Л. Годун, А.А. Дорошенко, Д.А. Муляр}

По результатам комплексного анализа установлено, что система контроля ядерной безопасности (СКЯБ) не полностью соответствует выдвигаемым к ней требованиям. По оценке достаточности точек детектирования этой регламентной системы установлено, что отсутствует мониторинг скоплений ядерноопасных делящихся материалов (ЯОДМ) в центральном зале и «северного» скопления ЯОДМ в помещении 305/2. Эффективность мониторинга «южного» скопления ЯОДМ в помещении 305/2 недостаточна и не соответствует нормам, регламентируемым «Правилами ядерной безопасности» (ПБЯ). Также не выполняется ряд других требований к СКЯБ как системы аварийной сигнализации хранилища отработанных 
ядерных отходов. Предлагается выполнить перекомпоновку измерительных каналов (ИК) системы, вывести из эксплуатации избыточные (неинформативные) ИК и использовать их оборудования для организации новых эффективных точек мониторинга; произвести модернизацию программного обеспечения и организовать индивидуальное заземление системы, чтобы снизить влияние высокочастотных наводок и помех.

\section{ОЦІНКА ЕФЕКТИВНОСТІ РЕГЛАМЕНТНОЇ СИСТЕМИ КОНТРОЛЮ ЯДЕРНОЇ БЕЗПЕКИ КОМПЛЕКСУ НБК-ОУ}

\section{Р.Л. Годун, А.О. Дорошенко, Д.О. Муляр}

За результатами комплексного аналізу встановлено, що система контролю ядерної безпеки (СКЯБ) у повному обсязі відповідає висунутим до неї вимогам. За оцінкою достатності точок детектування цієї регламентної системи встановлено, що відсутній моніторинг скупчень ядерно-небезпечних матеріалів, що діляться (ЯНДМ), у центральному залі і «північного» скупчення ЯНДМ в приміщенні 305/2. Ефективність моніторингу «південного» скупчення ЯНДМ у приміщенні 305/2 недостатня і не відповідає нормам, що регламентуються «Правилами ядерної безпеки» (ПЯБ). Також не виконується ряд інших вимог до СКЯБ як системи аварійної сигналізації сховища відпрацьованих ядерних відходів. Пропонується виконати перекомпонування вимірювальних каналів (ВК) системи, вивести 3 експлуатації надлишкові (неінформативні) ВК і використовувати їх обладнання для організації нових ефективних точок моніторингу; провести модернізацію програмного забезпечення та організувати індивідуальне заземлення системи, щоб знизити вплив високочастотних наведень і перешкод. 